\title{
Sistem Media Massa Indonesia di Era Reformasi: Perspektif Teori Normatif Media Massa
}

\author{
Nia Kurniati Syam \\ ABSTRACT \\ Social control as a means of mass media becomes very crucial in a democratic country. Within \\ this function, mass media has positioned itself to control executive decisions in development \\ process. But the functions of mass media are much more than to be a watchdog. As explored by \\ this article, many theories concerning mass media functions from normative perspective are \\ formulated by mass communication scholars. There are at least 6 (six) theories concerning \\ mass media system through which the function of mass media is derived: (1) Authoritarian; \\ (2) Free Press; (3) Social Responsibility; (4) Soviet Press; (5) Development Press; \\ (6) Democratic-Participant. As for Indonesia, in order to achieve national goals based on \\ democratic process, the press system must develop in ways that respected the diversity \\ of multicultural perspective and public opinion pluralism.
}

Kata kunci: sistem media massa, teori normatif, pers Indonesia.

\section{Pendahuluan}

Gerakan moral yang dimotori oleh para mahasiswa dan kalangan sivitas akademik, telah membawa bangsa Indonesia ke babak baru, yakni "era reformasi" yang menyeluruh dalam berbagai bidang kehidupan bernegara dan berbangsa. Salah satu implikasinya adalah reformasi di bidang media massa.

Upaya reformasi yang dimaksudkan, tentunya, diarahkan pada tujuan untuk mewujudkan suatu sistem dalam kehidupan media massa yang "demokratis, adil, bebas, dan bertanggung jawab".

Pengalaman di masa Orde Baru menunjukkan bahwa media massa di Indonesia berada dalam kondisi yang terkungkung, tidak berdaya, dari tekanan-tekanan kepentingan pihak penguasa dan pengusaha media. Tekanan-tekanan itu dilakukan dengan alasan demi stabilitas nasional dan kepentingan pembangunan ekonomi. Hal demikian jelas telah membuat media massa cenderung hanya berorientasi pada kepentingan pihak pemerintah dan pihak pemilik modal, dan mengabaikan kepentingan khalayak dan masyarakat luas.

Fungsi kontrol sosial dari media massa dalam menyampaikan kritikan serta pandangan yang berbeda mengenai realitas pembangunan cenderung menurun, bahkan tidak ada sama sekali. Dan, kalaupun ada yang melakukan kritikan, itu pun dilakukan ekstra hati-hati, karena konsekuensinya cukup besar yakni pencabutan SIUPP atau pembredelan. Padahal dalam UU Pokok Pers tidak dikenal istilah pembredelan, ini merupakan pelanggaran hukum oleh pemerintah. 
Dalam kondisi yang tertekan, maka bila kita cermati tidak mengherankan kalau pers yang dikatakan independen dan masih memiliki idealis selalu menggunakan sistem karet gelang guna menengahi kondisi yang serba tidak menguntungkan ini. Dan, akibatnya, kredibilitas media massa di mata khalayak semakin menurun. Dalam konteks ini, Deddy N Hidayat (1996) mengatakan bahwa melemahnya kredibilitas media massa nasional disebabkan oleh sistem komunikasi politik dan kebijakan politik media massa yang berlaku.

Ada dua faktor yang menjadi penyebab melemahnya kredibilitas media massa, yaitu: (1) Ketidakberdayaan para pengelola media massa menghadapi tekanan politik eksternal dalam mendefinisikan dan menggambarkan "realitas sosial". Tekanan eksternal ini akan memengaruhi objektivitas antarmedia, dan hasilnya media massa dalam pemberitaannya tidak lagi mampu menyajikan pluralitas sikap dan opini yang dapat memperkaya wawasan pemikiran khalayak; (2) Secara struktural, politik media yang berlaku di masa Orde Baru diasumsikan semakin memperkokoh integrasi vertikal dalam sistem komunikasi politik. Hal ini tercermin dengan dimilikinya berbagai media massa oleh elite politik yang diperkirakan memiliki keseragaman konsepsi mengenai realitas sosial. Pola demikian oleh khalayak luas akan dinilai kurang mewakili spektrum realitas sosial secara komprehensif dan objektif, karena tidak menyertakan versi-versi alternatif yang berada di luar horison pemikiran pihak-pihak pengendali massa.

Sehubungan dengan hal tersebut, penulis merasa tergerak untuk membahas masalah reformasi di bidang media massa. Di era reformasi ini, semua unsur bangsa, termasuk pers (media massa) memunyai kesempatan yang sama untuk memperbaiki segala sistem kehidupan yang dirasa buruk pada masa Orde Baru. Pers mempunyai kesempatan untuk meletakkan prinsip-prinsip dasar idealismenya sebagai pers yang adil, bebas, dan bertanggung jawab serta pers yang mampu menjaga keseimbangan di antara berbagai benturan kepentingan.

\section{Perumusan Masalah}

Sistem media massa yang bagaimana yang sesuai dengan tuntutan reformasi di tengah-tengah berbagai kepentingan yang memengaruhi kehidupan pers.

\section{Kerangka Teoretis}

\subsection{Teori Sistem Normatif Media Massa}

Pendekatan yang digunakan dalam membahas masalah di atas adalah Teori Sistem NormatifMedia Massa. Dennis Mc. Quail dalam bukunya Massa Communication Theory (1987), antara lain, menjelaskan enam ragam teori sistem normatif media massa yang dapat diterapkan dalam suatu negara, yaitu (1) Teori Sistem Pers Otoriter, (2) Teori Sistem Pers Bebas, (3) Teori Sistem Pers Tanggung Jawab Sosial, (4) Teori Sistem Pers Soviet, (5) Teori Sistem Pers Pembangunan, (6) Teori Sistem Pers Demokratis Partisipan. Dari enam teori tersebut, empat di antaranya (1 s.d. 4) merupakan buah pikiran Siebert, Peterson, dan Schramm yang terkenal dalam bukunya Four Theories Of The Pers (196).

(1) Teori Sistem Media Massa Otoriter.

Teori ini lazim diterapkan dalam masyarakat prademokrasi dan dalam masyarakat yang masih didominasi kekuatan otoriter. Prinsip umum dari teori sistem media massa otoriter adalah: (a) Media massa tidak boleh melakukan hal-hal yang dapat merusak wewenang yang berlaku; (b) Media harus tunduk pada pemegang otoritas kekuasaan; (c) Media harus menghindari perbuatan yang menentang nilainilai moral dan politik dari kalangan dominan atau mayoritas; (d) Sensorship dibenarkan untuk menegakkan prinsip-prinsip yang dianut; (e) Kecaman terhadap pemegang otoritas tidak dibenarkan; (f) Kalangan wartawan dan profesional tidak memiliki indenpensi dalam organisasi medianya.

(2) Teori Sistem Media Massa Bebas.

Teori ini muncul pada abad ke-17 sebagai reaksi atas kontrol penguasa terhadap pers, dan kini diterapkan di berbagai dunia yang 
menganut sistem demokrasi liberal. Beberapa prinsip dari teori ini adalah: (a) tidak ada penyensoran terhadap publikasi; (b) setiap orang bebas memiliki media dan tidak perlu ada izin atau lisensi; (c) kecaman terhadap pemerintah tidak bisa dipidana; (d) wartawan memiliki otonomi profesional yang kuat dalam organisasi medianya.

(3) Teori Sistem Media Massa Tanggung Jawab Sosial.

Teori ini didasarkan pada pertimbangan bahwa sistem pada pasar bebas, kenyataannya, telah gagal untuk memenuhi tujuan kebebasan pers dan tidak mampu melindungi kepentingan masyarakat banyak. Prinsip-prinsip utamanya: (a) media harus menerima dan memenuhi kewajiban tertentu kepada masyarakat; (b) kewajiban-kewajiban tersebut menyangkut keinformasian dengan standar kebenaran, akurasi, objektivitas dan keseimbangan; (c) media bebas dalam melaksanakan tugasnya; (d) media bersifat pluraristis dan merefleksikan kebinekaan masyarakat, memberikan kesempatan yang sama untuk mengekspresikan berbagai sudut pandang, serta memberikan jaminan hak jawab; (e) media harus menghindari diri dari setiap upaya yang menjurus kepada tindak kejahatan, kekerasan, merusak tatanan sosial, atau menyakiti kelompok-kelompok minoritas; (f) masyarakat dan publik memiliki hak untuk menuntut standar kinerja yang tinggi dari pers, dan karenanya intervensi dibenarkan mengingat media massa merupakan public good wartawan dan kalangan profesional bertanggung jawab terhadap masyarakat, pihak majikan, serta pasar.

(4) Teori Sistem Media Massa Soviet.

Prinsip utamanya adalah: (a) media merupakan kaki tangan penguasa; (b) kalangan swasta tidak dibenarkan memiliki media; (c) media harus memberikan pemikiran yang lengkap dan objektif mengenai masyarakat dan dunia sesuai dengan ajaran Marxisme dan Leninisme; (d) masyarakat berhak melakukan sensor dan memberikan hukuman dalam upaya mencegah publikasi yang sifatnya antisosial.

(5) Teori Sistem Media Massa Pembangunan.

Teori ini muncul tahun 60-an dan menjadi model di banyak negara berkembang, di Asia, Afrika, Amerika Latin. Prinsip utamanya: (a) media harus menginformasikan tugas-tugas positif pembangunan sesuai dengan kebijakan yang ditetapkan; (b) kebebasan media dibatasi sesuai dengan prioritas ekonomi dan kebutuhan masyarakat negara berkembang; (c) isi media memprioritaskan kebudayaan dan bahasa nasional; (d) memprioritaskan isi berita dan informasi tentang negara-negara tetangga; (e) wartawan memunyai tanggung jawab dan kebebasan dalam menjalankan tugasnya; (f) demi kepentingan negara dibenarkan untuk ikut campur, memberikan pembatasan, dan pengoperasioan media, melakukan penyesoran, memberikan subdisi, dan pengendalian secara langsung.

(6) Teori Sistem Media Massa Demokratis Partisipan.

Teori ini muncul belakangan dan diterapkan di negara-negara berkembang yang menganut paham liberal. Prinsip utamanya: (a) setiap orang berhak mendapatkan akses terhadap media dan berhak untuk dilayani; (b) media tidak tunduk pada penguasa; (c) eksistensi media ditujukan untuk kepentingan khalayak bukan untuk golongan tertentu; (d) setiap orang, kelompok, bebas memiliki media; (e) kebutuhan sosial tertentu yang terkait dengan media tidak cukup dikemukakan melalui tuntutan konsumen secara individual, ataupun melalui negara dan berbagai sasaran utama kelembagaan.

\subsection{Media Masaa vs Benturan Kepentingan}

Media massa sebagai lembaga atau institusional di Indonesia merupakan salah satu bagian atau subsistem sosial politik, karenanya kajian tentang permasalahan media massa tidak dapat dilepaskan dari kajian tentang permasalahan sistem politik, ekonomi, sosial, dan budaya yang berlaku di masyarakat atau negara di mana media 
tersebut tinggal.

Menurut McQuail (1987), operasional dan tujuan media massa di suatu negara ditentukan oleh beberapa pihak atau unsur.

Terhadap gambaran konseptual ini kita bisa melihat bahwa sebagai bagian dari sistem kenegaraan, maka kepentingan nasional, negara dan bangsa yang dirumuskan oleh kalangan pembuat kebijakan akan menentukan mekanisme operasionalisme media massa dalam menjalankan fungsi dan tujuannya. Misalnya, pihak pemerintah menginginkan agar media massa berfungsi sebagai sarana pemelihara integritas bangsa dan negara, sarana pemiliharaan kestabilan politik, dan lainlain. Sementara itu, pihak khalayak mengharapkan media massa berfungsi sebagai sumber informasi yang dipercaya, sarana pengetahuan budaya, dan lain-lain.

Bagi para pengusaha dan pemiliknya, media massa khususnya kalangan wartawan merupakan sarana bisnis. Sedangkan bagi para komunikator massa, khususnya, kalangan wartawan dan karyawan media masaa lainnya yang diutamakan adalah kepuasan profesi. Bagi kalangan tertentu, khususnya tokoh pemuka pendapat, media massa merupakan insfrastruktur kekuatan (power). Adapun kebijakan-kebijakan perundangundangan, peraturan, dan lain-lain, merupakan refleksi dari keterlibatan kalangan dominant class. Di pihak lain, kalangan masyarakat umum (subordinate class) merupakan media massa sebagai alat kontrol sosial dan perubahan.

Dari gambar 1, jelas bahwa media massa dihadapkan pada suatu dilema yakni menghadapi berbagai benturan kepentingan. Kelangsungan media massa, dengan demikian, tergantung pada bagaimana memelihara keseimbangan di antara berbagai benturan kepentingan tersebut.

\section{Gambar 1: operasional dan tujuan media massa di suatu negara ditentukan oleh beberapa pihak atau unsur.}

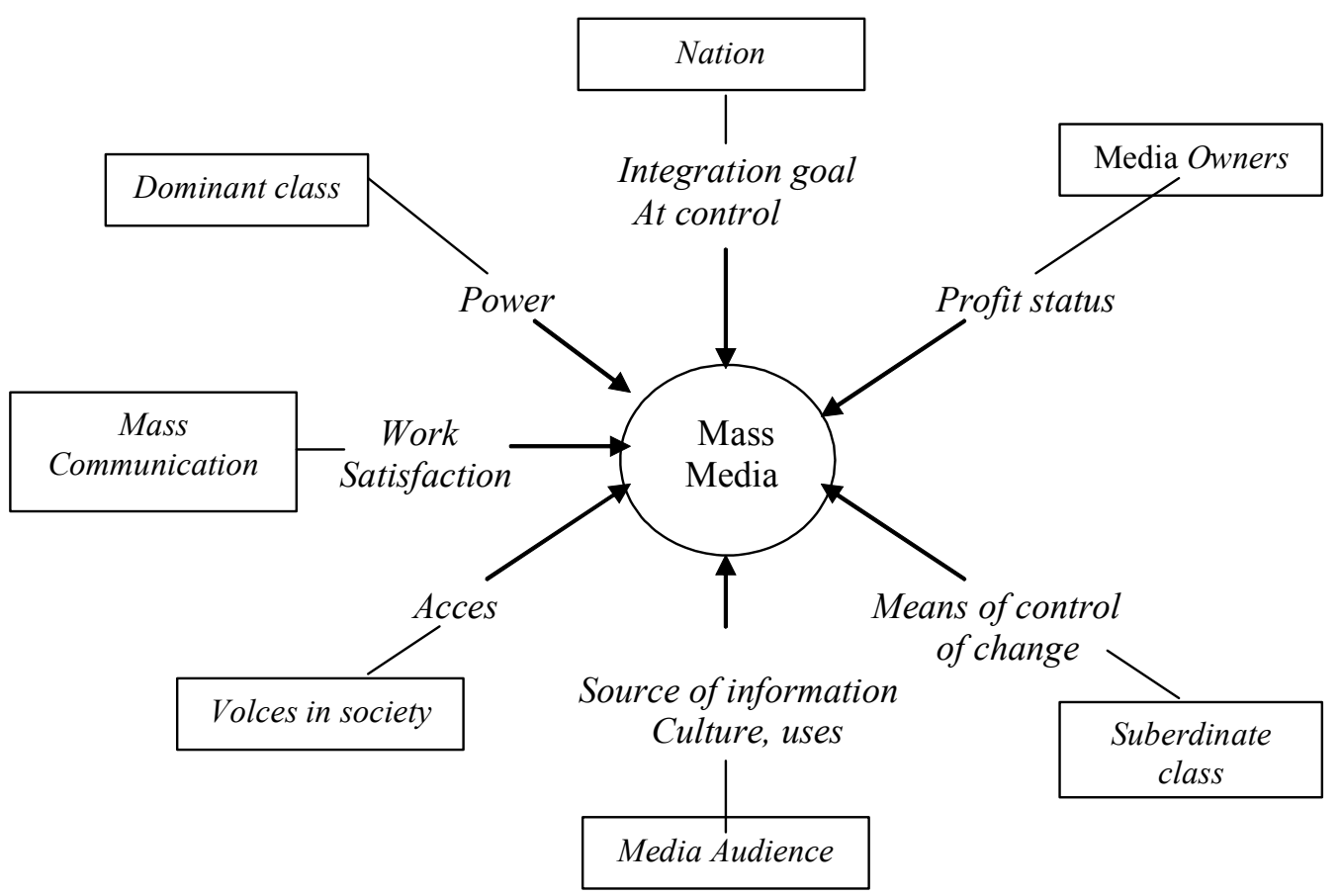

Sumber: McQuail (1987) 
Misalnya, apabila yang dipentingkan hanya kepentingan dan kebutuhan dominant class, maka media massa tersebut belum tentu akan laku, dalam arti banyak khalayaknya. Di pihak lain, apabila hanya mementingkan kepentingan dan kebutuhan khalayak, sementara kebutuhan dominant class diabaikan, maka bisa jadi media massa tersebut akan dikenakan tindakan hukuman.

\section{Pembahasan}

Sistem pers Pancasila yang selama ini dianut sepertinya menjadi bumerang bagi pers (media massa) Indonesia. Keterkungkungan sikap dan ketidakberdayaan serta monotonitas isi pemberitaan sepertinya menjadi ciri khas pers Pancasila. Kondisi ini menunjukkan bahwa sistem pers tidak berfungsi sebagaimana mestinya, yakni sebagai alat kontrol sosial dan bukan alat penguasa dan berpihak pada pengusaha dan kelompokkelompok tertentu yang berkepentingan.

Terjadinya reformasi di negara kita merupakan momen yang sangat tepat sekali dan membawa angin segar bagi kehidupan media massa. Karena, bagaimana pun media massa kita harus menyesuaikan diri dengan perkembangan di masa sekarang (era globalisasi) dan masa yang akan datang. Serta media massa juga harus memerhatikan berbagai kepentingan yang memengaruhinya sebagai sebuah sistem atau institusi sosial.

Guna menghadapi kondisi di atas, jelas pers Indonesia harus mereformasi diri. Menghadapi tantangan semacam ini, sungguh sangat tidak memungkinkan pers Indonesia bertahan dengan sistem pers Pancasila yang nota bene dalam prakteknya lebih banyak membatasi ruang gerak media massa.

Sependapat dengan Sasa Djuarsa Senjaya, (Jurnal ISKI, 1998) bahwa media massa Indonesia harus mulai mengarahkan orientasinya pada sistem media massa yang diarahkan pada upaya mewujudkan "sistem media massa yang demokratis dan adil bagi segenap bangsa Indonesia."

Sistem yang dimaksud pada dasarnya ditandai oleh beberapa prinsip dasar sebagai berikut:
(1) Sistem yang diterapkan seyogianya suatu sistem yang prinsip-prinsip operasionalnya merupakan gabungan atau kombinasi dari sistem tanggung jawab sosial, sistem media pembangunan, dan sistem media demokratis partisipan. Selama Orde Baru, kita mengenal sistem pers Pancasila, tetapi dalam prakteknya, teori sistem pers Pancasila tersebut ternyata tidak memperbaiki kehidupan media massa Indonesia, justru sebaliknya sistem pers Pancasila banyak diselewengkan pihak penguasa. Sehingga, tidak ada salahnya di era reformasi ini sistem pers Pancasila direformasi dan harus disesuaikan dengan perkembangan dan tuntutan zaman.

(2) Campur tangan pemerintah dalam bentuk regulasi atau pembatasan-pembatasan (undang-undang, peraturan menteri, dan lainlain) sebaiknya difokuskan pada hal-hal yang berkaitan dengan hak dan kewajiban media massa sebagai institusi sosial, politik, ekonomi. Sementara, yang menyangkut kebijaksanaan isi redaksionalnya diserahkan pada peraturan hukum peradilan yang berlaku. Implikasinya, izin atau lisensi (izin terbit dan izin siaran) tidak diperlukan lagi.

(3) Diperlukan perlindungan dan kepastian hukum yang menjamin kepentingan dan kebutuhan akses seluruh warga masyarakat sebagai khalayak media, termasuk terhadap kalangan minoritas etnis, agama, golongan politik. Selama ini, regulasi yang ada cenderung telah berorientasi kepada kepentingan penguasa dan pengusaha media.

(4) Prinsip Bhineka Tunggal Ika perlu tetap dipertahankan termasuk dalam hal dinamika pluralitas dan opini sikap. Kebebasan berpendapat ini merupakan ciri negara dan masyarakat yang benar-benar menghargai demokrasi. Kebebasan berpendapat dan berbicara ini tetap hraus mengacu pada ramburambu hukum.

(5) Pada tatanan sistem struktur sosial, kebebasan dan independensi media massa perlu ditingkatkan. Salah satu implikasinya adalah perlunya mengubah status badan hukum TVRI 
dan RRI menjadi otonomi independen. Dengan kata lain, statusnya berubah menajdi Public Broadcasting Service.

(6) Mengurangi semaksimal mungkin pengendalian atau kontrol dari pihak pemilik media terhadap kebijakan isi redaksional dan kreativitas wartawan dan pekerja profesional.

(7) Untuk mencegah terjadinya dampak sosial yang tidak diinginkan, diperlukan self censorship di kalangan pengelola media.

(8) Pengendalian birokrasi organisasi profesi media massa, seperti PWI, perlu ditiadakan. Untuk itu, dibenarkan munculnya berbagai asosiasi profesi media massa yang sesuai dengan aspirasi dan kepentingan kalangan profesional media massa.

(9) Dihilangkannya monopoli kepemilikan media massa.

(10) Eksistensi media massa lokal perlu lebih diberdayakan dengan mengurangi berbagai restriksi yang pada dasarnya memperlemah daya saing dan daya hidup media massa lokal tersebut.

\section{Penutup}

Sebagai penutup, dapat dikatakan bahwa upaya reformasi di bidang media massa pada dasarnya ditujukan pada tujuan untuk mewujudkan sistem dan kehidupan media massa nasional yang demokratis dan adil bagi segenap lapisan masyarakat. Untuk itu, perlu dilakukan upaya-upaya pembenahan secara menyeluruh yang mencakup berbagai aspek, dari sistem dan kebijaksanaan media massa nasional secara makro, sampai ke sistem dan pola pengelolaan berbagai aspek mikro operasional media massa. Sistem yang ideal tentu saja yang diharapkan mampu memenuhi tuntutan aspirasi dan kepentingan segenap lapisan masyarakat serta antisipatif terhadap tantangan dan perkembangan situasi era globalisasi komunikasi dan informasi di masa mendatang.

\section{Daftar Pustaka}

Mc. Quail, Dennis. 1987. Mass Communication Theory, An Introducton. Baverly Hills, California: Sage Publication.

Nur Hidayat, Deddy. 1996 "Politik Media dan Krisis Sistem Komunikasi,” Kompas, 27 Juni.

Siebert, F. Peterson, T., and W. Schramm. 1956. Four Theories of The Press. Urbana: University of Illionis Press.

Jurnal ISKI, Volume I, 1998. 